Ad Americam. Journal of American Studies 21 (2020):

ISSN: 1896-9461, https://doi.org/10.12797/AdAmericam.21.2020.21.08

Licensing information: CC BY-NC-ND 4.0

Valentin Petroussenko

Plovdiv University "Paisii Hilendarski," Plovdiv, Bulgaria

petrus@uni-plovdiv.bg

https:// orcid.org/0000-0002-2009-5444

\title{
Trajectory of Latin American Studies in Bulgaria
}

This article is a review of the development of Latin American Studies in Bulgaria since the very beginning of relations between this country and the remote continent in the Western Hemisphere. While research and publications in the first half of $20^{\text {th }}$ century were scarce and more of a travelogue genre, a new and genuine interest appeared after the revolution in Cuba, which was facilitated by close collaboration in respect to the socialist doctrine. Naturally, all research and publications during the Cold War had to fit ideological requirements. After 1989, the situation has changed and full freedom of scholarly research has allowed for a wide range of opinions to be voiced. However, Bulgaria entered a period of economic stagnation and lost most of its economic and trade ties with Latin America. As a result, there are significant difficulties in developing any studies beyond the European cultural space. Nevertheless, various attempts at refreshing connections with the Hispanic world on academic and other levels have been developed.

Key words: Latin American Studies; Bulgaria; research and culture

Cycles in our life repeat in fascinating ways and academic life is even more abundant with such unexpected surprises. On receiving the kind invitation to make a review of the small Bulgarian academic community dedicated to Latin American Studies, the chest of my memories suddenly opened. It was as long as thirty years ago-in the midst of my PhD studies - that I received a fabulous invitation to participate in an international conference organized by the Polish Academy of Sciences. My very first visit to Poland brought me to Warszawa and beyond: we went to a beautiful castle in Pultusk and the conference was memorable due to traditional Polish hospitality, the academic level, the first impression of highly respected scholarly openness, and equal treatment between the professors and us, young researchers. Honorable Professor Ryszard Stemplovski was the main figure as the organizer of the event that gathered many remarkable connoisseurs of the history of the distant continent at the time of starting our path in the transition to democracy, of which Poland was the pioneer. 
Beginning with my first international experience at this conference, which was followed by the first academic publication abroad (Petroussenko), my Polish cycles repeated many times. Some five years later, destiny brought me to the already well established Polish school of Latin America, managed by the CESLA from the Warsaw University and its charismatic director, the late Andrzej Dembicz. This collaboration enabled our small group of Bulgarian researchers of Latin America to enter the international scholarly structures of CEISAL, FIEALC, and ICA.

The example of our Polish colleagues was always very important, but unfortunately the two countries have completely different political, economic, and cultural ties with the Americas, one of the favoring factors in Poland being a considerable and closely knit Polish diaspora not only in the USA, but also in such countries as Argentina or Brazil. Hence, the importance of an academic institution closely working with the problems of Polish emigration, institutionally backed by the center of "diaspora studies" in Krakow. It is also important to notice the constant economic interest of entrepreneurs and an active role of the Polish state in maintaining diplomatic ties with Latin America. The Bulgarian situation was quite different, with dwindling trade contacts and the subsequent closure of many embassies.

Despite the generally pessimistic introduction about the position of Latin American Studies in Bulgaria, we may say that there is a credible record behind us, although we do not have so many experts, scholars or institutions dedicated to this type of academic research. There is one recent good review by Jordan Baev (Baev, 2017), but the issue still has some unedited data and needs more systematization. The picture of presentation of the Americas in Bulgaria begins in the middle of the $19^{\text {th }}$ century when the general milieu put a stronger emphasis on travelogue and non-fiction publications. Later, there were some early travelers who provided impressions from the New World as journalists or writers who personally saw what the Americas were like, but it is only after the Second World War that Latin American history entered a more global stage following the earlier adventurous period (Stefanova, Haitov, Karaivanova).

Bulgaria's connection with Latin America was considerably more distant, given the relatively late reestablishment of modern statehood in 1878 after five centuries of Ottoman domination. The Kingdom of Bulgaria, as a new-born country, was more busy with national reunification and confronting the jealous policies of neighboring Balkan powers. Since the whole peninsula served as a bridge between the East and the West, it always experienced the deep interest and aggressive involvement of the Great Powers in regional politics.

Involvement in local and regional conflicts (like the two Balkan Wars) and the First World War orientated the country towards regional politics even more but this dramatically ended with the defeat of the whole coalition and a tragic national catastrophe in 1918. Even these circumstances did not activate big emigration to America. Predominantly an agrarian society, Bulgaria soon recovered and enjoyed relative prosperity between the wars, despite the Great Depression of 1929. As a result, very small number of people were motivated to leave the country and seek better luck in other continents. However, the Bulgarian press always aroused public curiosity about the Americas and between the wars the first direct contacts were made on the level of insurgent political activity of Komintern envoys to Latin America - among them several Bulgarian Communists - like the father of the future Brazilian president Dilma Rouseff (Indjov). Although we do not know much about their activity 
there, one of the first authors recounting these events during the years of early Socialism in Bulgaria was Ivan Argentinski. Under this pseudonym, Ivan Bosyakov was a member of the Argentine Communist Party in 1930-1934, and later a prominent dramatist. He also penned three books dedicated to Argentina and Cuba (Argentinski). Seen from the diplomatic perspective, the earliest and longest connection of Bulgaria was with Argentina, and this country also had the biggest community of Bulgarian immigrants (Avramov e.a.); renewed attention has been attracted by such personalities as the prominent Argentine-Jewish artist Eliezer Nisim Alcheh. In 1951, he was expelled from Bulgaria, derogated for "aesthetics of disgrace." A tribute to him with extensive press coverage was paid in Sofia in September 2018 and earlier in 2008, on the occasion of his hundred year anniversary (Marinska).

Also among many Latin American leftist intelligentsia and workers, the very first knowledge of Bulgaria was embodied by the figure of "Jorge Dimitrov" through his brave confrontation with Hitler's propaganda during the Leipzig trial in 1933 (Baev, 1987, 1989). But far more intriguing was the figure of the late Teodoro Petkoff - renowned figure of Venezuelan radical leftist politics who at times was much disliked by the then Communist regime in Bulgaria for his extremism (Petkoff, Naumov).

However, the real first prolonged contacts between Bulgaria and Latin America started only after the Cuban Revolution in 1959. The events in the rebelling Caribbean island resulted in genuine sympathy towards brave and bearded young revolutionaries but also led to ideological support for the first socialist state in America. When Fidel Castro definitely opted for the Soviet support in the early '60s, Bulgaria became one of the most active supporters of the Cuban economy, and the number of Bulgarian technical advisers in Cuban agriculture and industry was second in size only to the Soviet community in Havana and throughout the island. This naturally brought great interest in Latin American culture and in 1961, a department of Hispanic Studies was founded in Bulgaria's oldest Sofia University, followed by other research institutions. Throughout the Socialist era, the most remarkable think-tanks dedicated to study of other continents were the following: Institute of Contemporary Social Theories, attached to the Communist Party "Academy of Social Management", and the Institute of International Relations and Socialist Integration, attached to the Bulgarian Academy of Sciences (Bashliev, 1977; Tosheva). Chilean themes also became very widespread during the Popular Unity governments and following the coup of 1973. Bulgaria also attracted a considerable Chilean community of political immigrants then, including the son of Luis Corvalan, who died of stroke in Sofia in the early' 80 s (Valkova; Galina).

Dependent on the ideological doctrine, these institutions mostly did economic research of the entire Third World with a special emphasis on the left-wing parties and trade unions in Latin America. Apart from that, very active contacts were established on the level of the so-called "organized workers" as well as by direct collaboration of the Communist and Agrarian Party instructors. Soon, these contacts were extended beyond the revolutionary Caribbean island but only insofar as a lawful collaboration was possible, like after the victory of the Sandinistas guerrillas in Nicaragua. Of course, on the level of intelligence or arms trade, there always existed close ties with the Latin American insurgents, but this is another secret story.

As regards academic research during this period, their focus was predominantly ideological. Namely, attention was turned toward eloquent appraisals of 
revolutions, left-wing legal syndicalism or guerrilla fights in Central America (Alexandrova; "Connections..."). The late '70s and early '80s were abundant in events with such dramatic results that were reflected in scholarly production focusing on blaming "US imperialism." However, despite the overwhelming ideological bias, there was a marked genre and methodological departure from the early travel books written mainly by journalists. Most prominent author among them was Nikola Indjov, who also served as a diplomat in Cuba and Mexico (acknowledged also as writer, essayist, and poet), with numerous literary works on Latin America and gradually more academic and analytical works, however always dependent on the classical revolutionary orientation (Nedyalkov, "History..."). But there always existed strong disparities among ideological regulations and the richness of the Latin American mentality. It might be seen in the famous Latin American literary works, which gained worldwide popularity at that time, also in Bulgaria. But even so, it was not easy to make translations of "magic realism" which was so attractive in the '80s with the books of Gabriel Garcia Marques; these were allowed because of his world fame and close friendship with Fidel Castro (Stoyanov); not so successful were the attempts to translate other authors of "magic realism," which were accused of being too dark and pessimistic. The same discrepancies were also seen on the ideological level as no information was disseminated about more radical Maoist content or the doctrine of focos guerrilleros under the idealized revolutionary symbol, Ernesto Che Guevara. Even Che's last diary as a Bolivian guerrilla was not allowed to be translated for the wider public.

Unfortunately, during all these years, Bulgaria was unable to build a stronger and unbiased scholarly institution working on Latin American themes and the lack of graduated scholars was compensated by providing some PhD scholarships in Soviet academic institutions. Direct contact with Latin America was possible only through Cuba and regrettably there were no active channels of travel and contact with experts on Latin America even in other COMECON countries (that is, apart from official diplomatic relations, but access to them was strictly controlled). Because of that, higher academic learning in the field of Hispanic Studies was only possible for Bulgarians at the Institute of Latin America in Moscow (ILA), attached to the Russian Academy of Sciences. Dimiter Bashliev was the first doctoral student; he graduated in the early '70s and went on to work extensively on the themes of Argentina and Chile. Then two other economists followed: Tchavdar Nikolov and Slavomir Georgiev, who obtained their PhDs in ILA during the early '80s and made afterwards their diplomatic careers, however without further scholarly publications. Then during the late stage of perestroika and dissolution of the USSR, this Russian direction of academic graduations came to an end by 1992 (Petroussenko). Since then, Bulgaria itself was able to provide high enough doctoral degrees in Latin American studies, and in the early 90s, the first two PhD thesis on these issues were completed within the Bulgarian Academy of Sciences at the Institute of Sociology (Hristov; Kolarov).

The situation suddenly changed after 1989, but it has had a twofold effect. On the one hand, scholars were now free to choose topics of research without any doctrinal limitations. This freedom did not bring more interest in Latin American topics, though. On the contrary, the urge to get access to liberal democracy, and most of all the new pro-European and NATO orientation, resulted in a decline of interest in other geopolitical regions. Apart from Latin America, this orientation affected also the 
Arab world as Bulgaria have lost most of its positions in the Middle East. This drastic breakdown was followed by cutting all contacts with the increasingly isolated Cuba and the rest of Central and South America. The trend affected mostly economic and trade contacts which were frozen after the drastic reduction of diplomatic ties.

The lack of a reasonable economic cooperation brought a gradual loss on the diplomatic front: from initially a dozen Latin American embassies accredited in Sofia, their number dropped to eight at first and just four at the present moment.

The beginning of the '90s saw the start of an emotional debate about the true story of the discovery of America by Columbus and Bulgaria indirectly entered this debate. The famous essay of Bulgaria-born French intellectual Tzvetan Todorov became very popular in the discourse on the right of the "discovered" Indians to a dignified treatment and it refreshed the discussion on that topic (Todorov). A prominent Bulgarian historian Andrei Pantev discussed the problem of the "other" and of the cultural clash in the interpretation of how the Americas were conquered with a focus on the separation of the Anglo-Saxon and Hispanic Americas (Pantev). Actually this was an early attempt to see the Americas from the point of view of a complex approach that is now called "Inter-American Studies", or observing the Americas in their own cultural and linguistic integrity.

However, despite these obstacles, the nucleus of experts and affiliated scholars working on Latin American issues persists in Bulgaria. These colleagues enjoy complete political freedom nowadays and indeed we see how some of them continue to embrace left-wing ideas, others maintain more balanced positions, and still others share more conservative views. The advantage of political freedom has resulted in more diversified approaches and platforms for conceptual debates. But the new reality also has odd limitations. There has been a growing interest in Latin America and the Hispanic world in general, but it is due to the popularity of Latino pop music and some cinema stereotypes. The other highly debated approach was related to the peculiarities of the democratic transition, especially in some parts of Eastern Europe or Balkan countries, where some analysts regard the features of corruption and authoritative government as closer to the Latin American model of democracy. Indeed, there have been slight resemblances in the early years of transition, but a total copying of the democratization process was not possible.

However, despite that the Bulgarian state has been continuously neglecting its involvement in other regions apart from the dominant Euro-Atlantic orientation; genuine and continuous interests in other continents have been preserved within the society. The oldest institution dedicated to studies of Latin America (and Luzo/ Iberoamerican studies in general) is the Department of Hispanic Studies at Sofia University "St. Kliment Ohridski." In 2011, they celebrated 50 years of their BA program and a year earlier they held a big conference on the occasion of "Bicentenario." But their profile tends to be predominantly linguistics oriented and partly covering cultural studies. Among most prominent figures, we may enumerate philologists Venko Kanev, Ivan Kanchev, and Rumen Stoyanov. The latter is a well-known translator of many Latin American authors like Julio Cortázar, Jorge Luis Borges, Alejo Carpentier, Gabriel Garcia Marques, and Fernando Pessoa, and also of the Maya historic epic Popol Wuj. He served as visiting lecturer in Mexico and later was the cultural attaché in Brazil. In 2012, he was the first Bulgarian to be awarded Doctor Honoris Causa title by the University of Brasilia. 
Regular courses on Latin American Studies were initiated in the early '90s in the first private university in the country: the New Bulgarian University (Petroussenko), but currently it is not operational due to the lack of enrolled students. A decade later similar courses were started, e.g. MA in the area of Ango-Saxon, French, and Hispanic Americas. Currently, a similar course is called Civilizations of the New World: Both Americas (Petroussenko). There is another place at South-Western University of Blagoevgrad, where Latin American themes are delivered. Though no special courses are provided, they have organized a conference in recent years and two doctoral students successfully completed their dissertations (Kantardjiev; Gospodinova). Another dissertation on the problems of aborigine Indian mentality through the conquest of America was developed in the work of Aneta Ikonomova through her PhD at the New Bulgarian University in 2019 (Ikonomova).

We may note another good but abortive attempt to launch a specialized "Center for Latin America" at Sofia University; it existed for about a couple of years and held two conferences, but failed to attract scholars from other institutions in order to become a representative national body. But since we mention such attempts at academic level, there have been several NGO's with orientation towards Latin America. In general, these were associations of friends, usually oriented towards a particular Latin American country (such as Cuba and Perú), and dependent on scarce support from the embassy and the dedication of their leaders. One more integrative event was the court registration of the Bulgarian-Latin American Association in the early '90s with a universal approach to the whole continent, but its activity was not very regular because of financial constraints.

Present times have brought many more possibilities of travel and research. Therefore, we now have a full range of political beliefs expressed in Latin American Studies. I may point out one still feels there is a strong trend towards the romantic left, which follows old revolutionary stereotypes, and it is predominantly represented by journalists who publish mainly on independent websites (like baricada. org, coordinated by journalist Kadrinka Kadrinova, who also covers much activity on hispanoperiodistas.com). Then we have some researchers with more conservative positions like Lazar Koprinarov, philosopher and former ambassador to Caracas (Koprinarov, 2011). Other publications tend to be more neutral and balanced; they fully cover all opinions and political trends and provide the specific Bulgarian view on the development of Latin America (Baev 2002, 2012; Pencheva; Alexieva; Hristov; Sivilov; Petroussenko 2003; Kolarov). Because of the lack of space, only books are cited, although the same authors have presented many more papers at academic forums or journals. No less interesting contributions come from some former diplomats, who now can provide uncensored memoirs (Andreev; Gerasimov). Although there are certain constraints in connecting with Latin American academic institutions through EU-based scientific and educational projects, especially in humanities, there are appearing more contacts and possibilities to do so. But it is worthwhile to mention in particular that the Central European educational network CEEPUS has long been supporting two special networks involved in Inter-American and Hispanic American Studies (C.IAS).

Yet, at the present moment it seems that the fates of Latin American Studies in our region has been more favorable to Bulgaria's neighboring countries as first Athens was hosting the FIEALC congress in 2009, then it was held in Turkish Antalya in 
2013, and later the congress was hosted by a private university in Belgrade in 2017. This summer Bucharest also joined this list of highly representative international forums when the CEISAL congress was hosted by the Department of Hispanic Studies at Szeged University, and thus we may say that the Balkans has ceased to be terra incognita for Latin American Studies. But any of these events requires to have a critical amount of experts working in the given scholarly event and very strong institutions to take the responsibility to host such kinds of academic events. Besides these indispensable factors, there must be really strong lobbying and at least some support from the local and national authorities.

The agenda now is to attract younger people and students to this new world and to find the ways to get support from public and private institutions in order to maintain high academic quality and intellectual level of Latin American Studies in Bulgaria.

\section{References}

Alexandrova, Maria. El movimiento obrero y syndical en América Latina. Sofia, Sofia Press, 1974. Alexieva, Gergana. “Peronism: Politics and Ideology," V.Turnovo. 2014.

Andreev, Elenko. The Gods Must Be Angry, Sofia, 2009 (short novel).

--- The Orgy of Masks, Sofia, 2011 (short novel).

Argentinski, Ivan. Distant Patagonia, 1947 (later editions in 1958, 1970, 1986).

--- Disobedient Cuba, Sofia, 1961.

--- My Argentine Youth, a memoirs novel from. Sofia, 1974.

Avramov, Rumen, e.a. Bulgarians in Argentina. Sofia, 1987. One of the few books about Bulgarian emigration in South America.

Baev, Jordan. "Jorge Dimitrov y la lucha revolucionaria en Nicaragua", El Nuevo Diario, Managua, 17 de Junio de 1987; Por la Unidad Democrática. Jorge Dimitrov y el movimiento revolucionario en América Latina, Sofia Press, 1989.

--- "Bulgaria and the Armed Conflict in Central America, 1979-1989," Armies and Politics. Moscow, 2002, pp. 33-45.

--- “Documents on Bulgarian-Cuban Relations, 1960-1975: New Evidences from the Sofia Archives," CWIHP Bulletin 17/18, Fall 2012.

--- "Stages in the Development of Bulgarian Historiography on Latin America During the Cold War" in Eastern Europe and Latin America. Sofia University, 2017.

Bashliev, Dimitar. Socio-Political Peculiarities of the Agrarian Problem in Latin America. Sofia, 1977.

--- Government of Popular Union in Chile 1970-1973. Sofia, 1982.

Connections of the Communist Parties in Latin America with the masses: The Experience of Argentine and Uruguayan Communists. Sofia, 1983.

CEEPUS funded networks - C.IAS (interamerikanistik.uni-graz.at/cias), with institutional member Plovdiv University and local coordinator V.Petroussenko; and RHEC (redhispanistaseuropacentral.wordpress.com) - again with institutional member Plovdiv University and local coordinator Veselka Nenkova.

Galina, Lada. Echoes from the Andes. Sofia, 1977.

Gerasimov, Bogomil. Diplomacy in the Zone of Cactus, 1998, 2008. (memoirs)

--- Kukulkan is Coming Down from the Heaven. Sofia, 1989, 2012. (travelogue)

--- Mysterious Power of the Pyramids. 2000, 2009. (esoteric essays)

Gospodinova, Zhiva. Economic Liberalization and Social Changes in Central America (1980s1990s), SWU, 2018. (PhD thesis) 
Haitov, Nikolai. Peruvian Notes. Sofia, 1975. (essays)

History of the Workers and Communist Movement in Latin America. Sofia, 1985.

Hristov, M. “Aspectos históricos y políticos de la democratización en Argentina y el papel de las Fuerzas Armadas", in Latin America in the Global World, SWU, 2015.

---“Historical and Sociopolitical Prerequisites of the Military Latin American Authoritarianism," Socio-economic Analyzes, Faculty of Economics, VTU, Vol.\#1, 2018.

Ikonomova, Aneta. Cohesion Between Indians and Spaniards During the Conquest of America. NBU, Sofia, 2019. (PhD thesis)

Indjov, Momchil, and Shade Jamil. Dilma Rouseff. History of a Bulgarian Family Marked by Exile, Communism and Presidency of Brazil. Sofia, 2011. (first published in Brazil)

Indjov, Nikola. Cubamar. Sofia, 1974. (essays, poetry)

Jara, Victor. Soul Wrapped by Flags. Sofia, 1978. (poetry and songs)

Kantardjiev. Alexander. Peculiarities and Development of the Regional Integration in Latin America and the Caribbean (1950s-1990s). SWU, 2017. (PhD thesis)

Karaivanova, Penka. USA. Who Lost Patagonia. Sofia, 1981. (Published only a year before the Falkland crisis!)

Kolarov, Georgi. Latin American Left by the End of $20^{\text {th }}$ century. Between the Sandinism and Senderism. Sofia, 1993.

Koprinarov, Lazar. "Presidency Mandate of Dilma Rouseff: Between the Legacy and the Change in Brasil," NotaBene 18 (2011) http:/ / notabene-bg.org/read.php?id=191.

--- "Deconstruction of the "Left Wave" in Latin America," NotaBene 19 (2011) http:/ / notabene-bg.org/read.php?id=204

Marinska, Ruzha. Eliezer Alcheh, Sofia, 1995.

Naumov, Lyuben. Venezuelan Patriots with Bulgarian Blood. The Story of Three Brothers - Teodoro, Lyuben and Miroslav Petkoff, Participants in Venezuelan Resistence. Sofia, 1965.

Nedyalkov, Lyubomir. Youth Revolutionary Movement in Latin America. Sofia, 1976.

Pantev, Andrei, Why Two Americas?. Sofia, 1991.

Pencheva, Eleonora. "Globalization, Regionalism and Socialism in Latin America," Actas II Jornadas de Hispanismo 2009-2010, Departamento de Estudios Iberoamericanos Universidad de Sofia "San Clemente de Ojrid" Instituto Cervantes de Sofia. Sofia, 2015.

--- "Globalization and Non-tolerance. The Experience of Central America," Globalization and Tolerance, Sofia, 2015: 152-165.

Petkoff, Teodoro. "Las dos izquíerdas," Nueva sociedad 197, mayo-junio 2005, pp. 114-129.

Petroussenko, Valentin. "The Ruling Elite: A Case Study of Bulgaria and Mexico During the Democratic Transition," Estudios Latinoamericanos, 14, vol.2, Fall 1992, Warsaw.

--- Mexico: From Progressive Reforms Towards Capitalist Modernization, 1946-1952. ILA-RAN, Moscow, 1992. (PhD thesis)

--- Formation of the Statehood in Latin America Since the Discovery and Till the Wars for Independence. Sofia, 2003.

--- (Authorship of three university courses of Latin American Studies in NBU, Sofia University and Plovdiv University).

Shopov, Kiril. Brazil: From Castelo Branco till Dilma Rouseff. Sofia, 2012.

Sivilov, Alexander. The First 11th September. Chile 1973-1993. Sofia, 2013.

--- A Hug from the Bear. USSR and Latin America. Sofia, 2016.

Stefanova, Lilyana. Volcanoes of Mexico Smoke. Sofia, 1969.

Stoyanov, Roumen - interview for Novinar newspaper, 04.02.2011

Tosheva, Svoboda. Peculiarities of economic development of Latin American countries and perspectives for cooperation with Bulgaria. Sofia, 1977.

Todorov, Tzvetan. Conquest of America. The Question of the Other. Harper \& Row, 1984.

Valkova, Ivaila. Chilean spring. Sofia, 1973. 